\title{
SUPLEMETASI VITAMIN E DALAM CAIRAN RUMEN IN VITRO: ANALISIS PARAMETER FERMENTASI
}

\section{VITAMIN E SUPPLEMENTATION IN IN VITRO RUMINAL FLUID: ANALYSIS OF FERMENTATION PARAMETERS}

\author{
Firman Nasiu ${ }^{1 *}$, Lies Mira Yusiati ${ }^{2}$, dan Supadmo ${ }^{2}$ \\ ${ }^{1}$ Fakultas Peternakan, Univesitas Halu Oleo, Kendari, 93232 \\ ${ }^{2}$ Departemen Nutrisi dan Makanan Ternak, Fakultas Peternakan, Universitas Gadjah Mada, \\ Yogyakarta, 55281
}

Submitted: 30 April 2016, Accepted: 15 June 2016

\section{INTISARI}

\begin{abstract}
Penelitian ini bertujuan untuk mengetahui pengaruh vitamin $\mathrm{E}$ terhadap parameter fermentasi dengan sistem fermentasi in vitro menggunakan cairan rumen kambing Bligon jantan. Substrat yang digunakan dalam proses fermentasi terdiri atas $65 \%$ rumput raja, $20 \%$ bekatul, dan $15 \%$ bungkil kacang kedelai dengan penambahan $3 \%$ capsulated crude palm oil (CCPO). Sistem fermentasi secara in vitro dibagi dalam 3 kelompok perlakuan: tanpa suplementasi vitamin E sebagai kelompok pertama (R0), suplementasi vitamin E 200 mg per kg bahan kering pakan sebagai kelompok kedua (R1), dan suplementasi vitamin E 400 mg sebagai kelompok ketiga (R2). Semua kelompok diinkubasi selama 48 jam menggunakan metode Menke dan Steingass. Hasil penelitian menunjukkan bahwa suplementasi vitamin E sampai level $400 \mathrm{mg}$ tidak berpengaruh terhadap parameter fermentasi (VFA, $\mathrm{NH}_{3}$, dan $\mathrm{pH}$ ) cairan rumen.
\end{abstract}

(Kata kunci: In vitro, Parameter fermentasi, Vitamin E)

\section{ABSTRACT}

The aim of this study was to examine the effect of vitamin $E$ on fermentation parameters by using an in vitro fermentation system with ruminal fluid from male Bligon goats. Substrats used in fermentation process comprised of $65 \%$ of king grass, $20 \%$ of rice bran, and $15 \%$ of soybean meal, with additional $3 \%$ of capsulated crude palm oil (CCPO). Treatments of an in vitro fermentation were divided into 3 groups, those are group without vitamin E supplementation (RO), group with $200 \mathrm{mg}$ per $\mathrm{kg}$ DM vitamin E supplementation (R1), and $400 \mathrm{mg}$ vitamin E supplementation (R2). All groups were incubated for 48 hours according to Menke and Steingass method. Results showed that vitamin E supplementation at the level of $400 \mathrm{mg}$ did not affect fermentation parameters (VFA, $\mathrm{NH}_{3}$, and $\mathrm{pH}$ ) on ruminal fluid.

(Key words: Fermentations parameters, In vitro, Vitamin E)

\section{Pendahuluan}

Vitamin E diketahui dapat memperbaiki kinerja ternak ruminansia (Macit et al., 2003). Vitamin E merupakan antioksidan biologis potensial yang diperoleh hanya melalui makanan. Fungsi utama vitamin E adalah sebagai antioksidan pemutus rantai produksi radikal bebas dalam sel membran (Channon dan Trout, 2002) dan untuk memindahkan hidrogen fenolat kepada radikal bebas peroksil dari PUFA yang telah mengalami peroksidasi (Murray et al., 1996). Penyerapan vitamin $\mathrm{E}$ dari saluran pencernaan dapat

\footnotetext{
* korespondensi (corresponding author):

Telp. +62 8114092627

E-mail: firman_nasiu@yahoo.com
}

diperbaiki dengan adanya lemak. Sebagai sumber lemak pakan dapat digunakan minyak sawit terproteksi (capsulated crude palm oilCCPO) (Tiven, 2011). Oleh karena itu suplementasi minyak dalam ransum diharapkan akan meningkatkan penyerapan vitamin E, menghasilkan konsentrasi vitamin E yang lebih tinggi dalam sel darah merah (Aharoni et al., 2005). Secara normal, konsentrasi vitamin $\mathrm{E}$ yang tertinggi adalah di dalam plasma, hati, dan jaringan lemak.

Gangguan absorbsi lemak akan menimbulkan defisiensi vitamin E karena tokoferol larut dalam lemak makanan dan dibebaskan serta diserap selama proses 
pencernaan lemak (Murray et al., 1996). Lebih lanjut dinyatakan, vitamin $\mathrm{E}$ diangkut dalam darah oleh lipoprotein melalui penyatuan ke dalam kilomikron yang mendistribusikan vitamin tersebut ke jaringan yang mengandung lipoprotein lipase kemudian ke hati, dan melalui pengeluaran dari hati di dalam lipoprotein berdensitas sangat rendah (VLDL). Vitamin E disimpan dalam jaringan adiposa.

Vitamin $\mathrm{E}$ diketahui tidak mengalami degradasi di dalam rumen (Leedle et al., 1993; McDiarmid et al., 1994) sehingga dapat berfungsi sebagai antioksidan di dalam proses metabolisme sel tubuh. Han dan Owens (1999) menyatakan bahwa vitamin E dalam bentuk $\alpha$-tocopherol tidak mengalami degradasi di dalam rumen dan $\alpha$-tocopheryl acetate tidak secara ekstensif berubah menjadi $\alpha$-tocopherol. Penelitian ini dilaksanakan untuk mengetahui pengaruh vitamin $E$ terhadap parameter fermentasi cairan rumen in vitro sehingga dapat memberikan informasi mengenai penggunaan vitamin $\mathrm{E}$ pada ternak ruminansia.

\section{Materi dan Metode}

\section{Pengujian in vitro}

Minyak sawit kasar (crude palm oilCPO) dicampur secara merata dengan susu bubuk afkir dengan perbandingan $1: 2$. Susu bubuk afkir ini berfungsi sebagai sumber protein yang akan berikatan dengan formaldehid untuk melindungi lemak. Campuran CPO dan susu bubuk afkir ditambahkan formaldehid teknis 37\% dengan level 2\% (Tiven, 2011) dari berat campuran tersebut kemudian dicampur kembali secara merata sehingga membentuk CPO yang terkapsulasi (Capsulated Crude Palm OilCCPO).

Analisis parameter fermentasi secara in vitro dilakukan terhadap ransum yang mengandung CCPO pada level vitamin E yang berbeda. Sebanyak 27 botol fermentor dibagi dalam 3 kelompok perlakuan, tiap kelompok terdiri dari 9 botol. Masing-masing botol sebagai fermentor diisi dengan rumput gajah, bekatul, bungkil kedelai dengan jumlah total $300 \mathrm{mg}$ yang kemudian ditambahkan CCPO 3\% dari bahan kering pakan. Kelompok 1 tidak diisi dengan vitamin $\mathrm{E}$, sedangkan kelompok 2 dan 3 masing-masing diisi dengan vitamin $\mathrm{E}$ sebanyak 0,06 mg (200 mg per kg bahan kering) dan 0,12 mg (400 mg per kg bahan kering pakan) (Karami et al.,
2011). Pada semua botol fermentor ditambahkan $30 \mathrm{ml}$ campuran cairan rumen kambing Bligon dan buffer, kemudian botol fermentor ditutup dan diklem. Botol fermentor diinkubasi pada suhu $39^{\circ} \mathrm{C}$ selama 48 jam dalam keadaan anaerob sesuai metode Menke dan Steingass (1988) yang telah dimodifikasi oleh Ranilla et al. (2001).

\section{Pengujian parameter fermentasi}

Pengujian parameter fermentasi rumen dilakukan dengan menuang cairan fermentasi dari dalam botol fermentor ke dalam tabung reaksi dan disentrifus dengan kecepatan 500 g selama 15 menit untuk memisahkan partikel pakan. Filtrat yang diperoleh dari hasil sentrifugasi ini digunakan untuk penentuan kadar $\mathrm{NH}_{3}$ (Weatherburn, 1967), total VFA (metode gas chromatography), dan pH (Abreu et al., 2004).

\section{Analisis data}

Data yang diperoleh diuji secara statistik menggunakan ANOVA dengan rancangan acak lengkap pola searah program SPSS versi 17.0 (Chicago, IL, USA). Perbedaan antar perlakuan diuji lanjut dengan Duncan's New Multiple Range Test.

\section{Hasil dan Pembahasan}

Pengaruh suplementasi vitamin $E$ terhadap parameter fermentasi cairan rumen dapat dilihat pada Tabel 1.

Amonia. Hasil penelitian menunjukkan bahwa level vitamin $\mathrm{E}$ yang berbeda tidak berpengaruh nyata terhadap rerata kadar $\mathrm{NH}_{3}$ cairan fermentasi yang ditunjukkan dengan kadar $\mathrm{NH}_{3}$ pada perlakuan tanpa suplementasi vitamin E, vitamin E $200 \mathrm{mg}$ dan vitamin E $400 \mathrm{mg}$ masing-masing sebesar $47,09 \mathrm{mg} / 100 \mathrm{ml}, 54,61 \mathrm{mg} / 100 \mathrm{ml}$ dan 52,17 $\mathrm{mg} / 100 \mathrm{ml}$. Salah satu faktor yang mempengaruhi konsentrasi $\mathrm{NH}_{3}$ dalam cairan fermentasi adalah kecepatan proses degradasi protein pakan. Konsentrasi $\mathrm{NH}_{3}$ rumen bervariasi tergantung pada jumlah protein pakan, laju degradasi protein dan waktu setelah pemberian pakan. Di dalam rumen protein mengalami hidrolisis menjadi peptida dan asam amino oleh aktifitas enzim mikroba. Selanjutnya asam amino oleh aktifitas mikroba mengalami deaminasi menghasilkan $\mathrm{NH}_{3}$ (Hungate, 1966).

Bakteri dan protozoa merupakan mikrobia proteolitik yang berperan penting dalam proses degradasi protein pakan di 
Tabel 1. Kadar $\mathrm{NH}_{3}, \mathrm{VFA}$, dan $\mathrm{pH}$ cairan rumen fermentasi dengan level vitamin $\mathrm{E}$ yang berbeda (rerata \pm SD)

$\left(\mathrm{NH}_{3}\right.$ content, $\mathrm{VFA}$, and $\mathrm{pH}$ of fermentation ruminal fluid with different level of vitamin $\mathrm{E}$ (average $\left.\pm D S\right)$ )

\begin{tabular}{|c|c|c|c|c|}
\hline \multirow{2}{*}{$\begin{array}{l}\text { Parameter fermentasi (fermentation } \\
\text { parameters) }\end{array}$} & \multicolumn{3}{|c|}{$\begin{array}{c}\text { Level vitamin } \mathrm{E}(\mathrm{mg} / \mathrm{kg} \mathrm{BK})(\text { level of } \\
\text { vitamin } E(\mathrm{mg} / \mathrm{kg} D M))\end{array}$} & \multirow{2}{*}{$\begin{array}{c}\text { Tingkat } \\
\text { signifikasi } \\
\text { (signification } \\
\text { level) }\end{array}$} \\
\hline & 0 & 200 & 400 & \\
\hline $\mathrm{NH}_{3}(\mathrm{mg} / 100 \mathrm{ml})\left(\mathrm{NH}_{3}(\mathrm{mg} / 100 \mathrm{ml})\right)$ & $47,09 \pm 9,04$ & $54,61 \pm 5,15$ & $52,17 \pm 11,81$ & ns \\
\hline \multicolumn{5}{|l|}{$\operatorname{VFA}(\mathrm{mM} / \mathrm{L})(\operatorname{VFA}(\mathrm{mM} / \mathrm{L}))$ : } \\
\hline Asetat (acetate) & $8,16 \pm 1,48$ & $9,18 \pm 0,49$ & $10,04 \pm 0,27$ & ns \\
\hline Propionat (propionate) & $2,65 \pm 0,35$ & $3,02 \pm 0,31$ & $3,15 \pm 0,23$ & $n s$ \\
\hline Butirat (butyrate) & $0,97 \pm 2,00$ & $1,66 \pm 0,96$ & $1,08 \pm 0,07$ & ns \\
\hline Total VFA (total of VFA) & $11,79 \pm 1,86$ & $13,86 \pm 1,43$ & $14,27 \pm 0,49$ & $n s$ \\
\hline Rasio C2:C3 (C2:C3 ratio) & $3,07 \pm 0,20$ & $3,05 \pm 0,24$ & $3,20 \pm 0,15$ & $n s$ \\
\hline $\mathrm{pH}(p H)$ & $6,54 \pm 0,16$ & $6,55 \pm 0,16$ & $6,55 \pm 0,16$ & $n s$ \\
\hline
\end{tabular}

ns Tidak berbeda nyata (non significant different).

dalam rumen. Bakteri dan protozoa menghasilkan enzim protease, peptidase, dan deaminase untuk mendegradasi protein menjadi asam amino, peptida, dan akhirnya menjadi amonia (Chuzaemi dan Bruchem, 1990). Stern et al. (2006) menyatakan bahwa degradasi protein dalam rumen merupakan hasil dari aktifitas mikrobia tergantung pada tipe protein, laju aliran rumen, $\mathrm{pH}$ rumen, substrat yang dapat difermentasi, dan spesies flora rumen yang dominan. Diperkirakan bakteri dan protozoa proteolitik banyak terdapat pada cairan fermentasi.

Hasil penelitian cairan fermentasi pada suplementasi vitamin $\mathrm{E}$ menunjukkan kadar $\mathrm{NH}_{3}$ masih dalam batas normal untuk pertumbuhan mikrobia sebagaimana yang dinyatakan oleh Satter dan Slyter (1972) bahwa kadar $\mathrm{NH}_{3}$ sampai $80 \mathrm{mg} / 100 \mathrm{ml}$ tidak mengganggu pertumbuhan mikrobia rumen, dengan demikian dapat dinyatakan bahwa penambahan vitamin $\mathrm{E}$ dalam cairan rumen in vitro tidak mengganggu produksi $\mathrm{NH}_{3}$ oleh mikrobia rumen.

Volatile fatty acid (VFA). Hasil penelitian menunjukkan bahwa level vitamin $\mathrm{E}$ yang berbeda tidak berpengaruh nyata terhadap rerata kadar VFA (asetat, propionat, dan butirat), total VFA, maupun rasio $\mathrm{C2:C3}$ cairan fermentasi yang ditunjukkan dengan konsentrasi total VFA cairan fermentasi pada perlakuan tanpa suplementasi vitamin $E$, vitamin E $200 \mathrm{mg}$, dan vitamin E $400 \mathrm{mg}$ masing-masing sebesar 11,79 mM, 13,86 $\mathrm{mM}$, dan 14,27 mM. Hasil tersebut menunjukkan bahwa penambahan vitamin $E$ dalam cairan rumen in vitro tidak mengganggu produksi VFA oleh mikrobia rumen. McDonald et al. (2002) menyatakan bahwa konsentrasi VFA dalam rumen antara 0,2-1,5 g/100 ml (10-70 mM/L).

Rasio asetat:propionat:butirat pada perlakuan tanpa suplementasi vitamin $\mathrm{E}$, suplementasi vitamin E $200 \mathrm{mg}$, dan suplementasi vitamin E $400 \mathrm{mg}$ berturut-turut adalah 69,27:22,48:8,25; 66,21:21,82:11,97; dan 70,35:22,06:7,59. Proporsi asetat:propionat tersebut masih berada dalam kisaran hasil penelitian Bergman et al. (1965) yang menunjukkan bahwa proporsi asetat:propionat:butirat cairan rumen domba berturut-turut berkisar antara 63 - 70\%:17 21\%:11 - 16\%. Proporsi asetat yang lebih tinggi dibandingkan dengan propionat disebabkan karena pakan dalam cairan fermentasi banyak mengandung serat dengan adanya bahan pakan hijauan sebanyak 65\% dari total pakan dibandingkan dengan konsentrat sebanyak 35\%. Pakan yang kaya akan glukosa meningkatkan produksi propionat sementara pakan yang kaya serat meningkatkan produksi asetat (Dijkstra, 1994). Selanjutnya dinyatakan bahwa proporsi relatif VFA yang diproduksi dipengaruhi oleh sejumlah faktor termasuk komposisi substrat, ketersediaan substrat dan laju depolimerisasi, dan spesies mikrobia yang ada.

Konsentrasi total VFA pada cairan fermentasi juga dipengaruhi oleh nilai $\mathrm{pH}$ yang tetap stabil sekitar 6,54-6,55. Erfle et al. (1982) menyimpulkan produksi VFA menurun ketika $\mathrm{pH}$ rumen turun dari 7 ke 5 , karena enzim yang penting untuk memecah serat tidak dapat berfungsi secara efektif pada $\mathrm{pH}$ di bawah 6 dan laju pertumbuhan bakteri fibrolitik menurun secara nyata pada $\mathrm{pH}$ yang rendah (Russel dan Wilson, 1996). Sung et al. 
(2007) menyatakan bahwa produksi VFA pada $\mathrm{pH}$ 6,2 dan 6,8 lebih tinggi dibandingkan pada pH 5,7. Mouriño et al. (2001) menyatakan bahwa $\mathrm{pH}$ merupakan faktor yang paling penting yang dapat mempengaruhi fermentasi selulosa di dalam rumen dan bakteri selulolitik dapat berkerja optimal pada $\mathrm{pH}$ di atas 6. Hasil tersebut menunjukkan bahwa penambahan vitamin $\mathrm{E}$ dalam cairan rumen in vitro tidak mengganggu produksi VFA.

Bakteri selulolitik tidak dapat bekerja optimal pada $\mathrm{pH}$ yang rendah (Russel dan Wilson, 1996). Bakteri merupakan mikrobia pencerna serat kasar yang utama di dalam rumen. Bakteri fibrolitik Fibrobacter succinogenes, Ruminococcus flavefaciens, dan Ruminococcus albus, secara umum diketahui sebagai organisme utama yang bertanggungjawab terhadap degradasi dinding sel tanaman di dalam rumen (Wang dan McAllister, 2002). Untuk dapat mendegradasi selulosa maka bakteri mengekskresikan enzim selulase. Enzim selulase mendegradasi selulosa melalui aksi sinergi dari aktivitas tiga enzim yaitu endoglukanase yang juga disebut carboxymethyl cellulase (CMCase) (endo$1,4-\beta$-D-glucanase), eksoglukanase (yang juga disebut sebagai cellobiohydrolase) (exo$1,4-\beta$ - $D$-glucanase), dan $\beta$-glukosidase $(1,4-$ $\beta$-D-glucosidase) (Li et al., 2006; Gao et al., 2008 cit. Gori dan Malana, 2010). Selanjutnya dinyatakan bahwa konsentrasi VFA dipengaruhi oleh aktivitas CMCase yang berperan penting dalam degradasi selulosa karena merupakan enzim utama dari enzim kompleks selulase yang berperan dalam mencerna selulosa.

Derajat keasaman (pH). Hasil penelitian menunjukkan bahwa level vitamin E yang berbeda tidak berpengaruh nyata terhadap rerata nilai $\mathrm{pH}$ cairan fermentasi. Nilai $\mathrm{pH}$ dalam cairan fermentasi yang rerata berkisar 6,54 - 6,55 tersebut ternyata masih dalam batas untuk pertumbuhan mikrobia yang optimal. Hal tersebut memperlihatkan bahwa penambahan vitamin E dalam cairan rumen in vitro tidak menggangu derajat keasaman cairan rumen. Nilai $\mathrm{pH}$ rumen bervariasi, pakan yang mengandung banyak biji-bijian akan menyebabkan penurunan $\mathrm{pH}$ sampai di bawah 5,0 dan pakan berserat dapat menyebabkan kenaikan $\mathrm{pH}$ sampai di atas 7,0 (Erfle et al., 1982). Krause et al. (2002) menyatakan, nilai $\mathrm{pH}$ rumen dipengaruhi oleh konsentrasi serat dalam pakan. Nilai $\mathrm{pH}$ rumen dapat mempengaruhi produksi $\mathrm{NH}_{3}$ dan VFA dalam rumen karena aktivitas mikrobia rumen dapat dipengaruhi oleh pH. Stern et al. (2006) menyatakan degradasi protein dalam rumen merupakan hasil dari aktifitas mikrobia yang dapat dipengaruhi oleh $\mathrm{pH}$ rumen. Sementara itu Erfle et al. (1982) menyimpulkan produksi VFA menurun ketika $\mathrm{pH}$ rumen turun dari 7 ke 5, karena enzim yang penting untuk memecah serat tidak dapat berfungsi secara efektif pada $\mathrm{pH}$ di bawah 6 dan laju pertumbuhan bakteri fibrolitik menurun secara nyata pada $\mathrm{pH}$ yang rendah (Russel dan Wilson, 1996).

\section{Kesimpulan}

Berdasarkan hasil penelitian yang telah dilaksanakan dapat disimpulkan bahwa suplementasi vitamin E sampai dengan level $400 \mathrm{mg}$ per $\mathrm{kg}$ bahan kering pakan tidak berpengaruh terhadap parameter fermentasi $\left(\mathrm{NH}_{3}\right.$, VFA, dan $\left.\mathrm{pH}\right)$ di dalam cairan rumen in vitro.

\section{Daftar Pustaka}

Abreu, A., J. E. Carulla, C. E. Lascano, T. E. Diaz, M. Kreuzer, and H. D. Hess. 2004. Effect of Sapindus saponaria fruits on ruminal fermentation and duodenum nitrogen flow of sheep fed a tropical grass diet with and without legume. J. Anim. Sci. 82: 1392-1400.

Aharoni, Y., A. Orlov, A. Brosh, R. Granit, and J. Kanner. 2005. Effect of soybean oil supplementation of high forage fattening diet on fatty acid profiles in lipid depots of fattening bull calves, and their levels of blood vitamin $E$. Anim. Feed Sci. Tech. 119: 191-202.

Bergman, E. N., R. S. Reid, M. G. Murray, J. M. Brockway, and F. G. Whitelaw. 1965. Interconversions and production of volatile fatty acids in the sheep rumen. Biochem. J. 97: 53-58.

Channon, H. A. and G. R. Trout. 2002. Effect of tocopherol concentration on rancidity development during frozen storage on a cured and uncured processed pork product. Meat Sci. 62: 9-17.

Chuzaemi, S. dan J. V. Bruchem. 1990. Fisiologi Nutrisi Ruminansia. Universitas Brawijaya, Malang. 
Dijkstra, J. 1994. Production and absorption of volatile fatty acid in the rumen. Livest. Prod. Sci. 39: 61-69.

Erfle, J. D., R. J. Boila, R. M. Teather, S. Mahadevan, and F. D. Sauer. 1982. Effect of $\mathrm{pH}$ on fermentation characteristics and protein degradation by rumen microorganisms in vitro. $\mathrm{J}$. Dairy Sci. 8:1457-1464.

Gori, M. I. and M. A. Malana. 2010. Production of carboxymethyl cellulase from local isolate of Aspergillus species. Pak. J. Life Soc. Sci. 1: 1-6.

Han, H. and F. N. Owens. 1999. Degradation of tocopherol and tocopheryl acetate by ruminal contents in vitro. Anim. Sci. Res. Rep. 119-125.

Hungate, R. E. 1966. The Ruminant and It's Microbes. Agricultural Experimental Station, University of California. Academic Press. New York, San Fransisco, London.

Karami, A., A. R. Alimon, A. Q. Sazili, Y. M. Goh, and M. Ivan. 2011. Effects of dietary antioxidants on the quality, fatty acid profile, and lipid oxidation of longissimus muscle in Kacang goat with aging time. The American Meat Science Association.

Krause, K. M., D. K. Combs, and K. A. Beauchemin. 2002. Effects of forage particle size and grain fermentability in midlactation cows. II. Ruminal $\mathrm{pH}$ and chewing activity. J. Dairy Sci. 85: 19471957.

Leedle, R. A., J. A. Z. Leedle, and M. D. Butine. 1993. Vitamin $E$ is not degraded by ruminal microorganism : assessment with ruminal contents from a steer fed a high-concentrate diet. J. Anim. Sci. 71: 3442-3450.

Macit, M., V. Aksakal, E. Emsen, M. I. Aksu, M. Karaoglu, and N. Esenbuga. 2003. Effects of vitamin $\mathrm{E}$ supplementation on performance and meat quality traits of Morkaraman male lambs. Meat Sci. 63: 51-55.

McDiarmid, R. E., W. Majak, and K. J. Cheng. 1994. Procedure for analysis of a-tocopherol acetate in bovine ruminal fluid. Can. J. Anim. Sci. 74: 391-392.

McDonald, P., R. A. Edwards, S. F. D. Greenhalgh, and C. A. Morgan. 2002.
Animal Nutrition. $6^{\text {th }}$ ed. Pearson Education Limited.

Menke, K. H. and H. Steingass. 1988. Estimation of the energetic feed valuiuhuoe obtained from chemical analysis and in vitro gas production using rumen fluid. Anim. Res. Dev. 28: 7-55.

Mouriño, F., R. Akkarawongsa, and P. J. Weimer. 2001. Initial $\mathrm{pH}$ as a determinant of cellulose digestion rate by mixed ruminal microorganisms in vitro. J. Dairy Sci. 84: 848-859.

Murray, R. K., D. K. Granner, P. A. Mayes, and V. W. Rodwell. 1996. Biokimia Harper (Harper's Biochemistry) Edisi 24, diterjemahkan oleh dr. Andry Hartono, D.A.N. Penerbit Buku Kedokteran EGC, Jakarta.

Ranilla, M. J., M. D. Carro, S. Lopez, C. J. Newbold, and R. J. Wallace. 2001. Influence of nitrogen source on the fermentation of fibre from barley straw and sugarbeet pulp by ruminal microorganism in vitro. Br. J. Nutr. 86: 717-724.

Russel, J. B. and D. B. Wilson. 1996. Why are ruminal cellulolytic bacteria unable to digest cellulose at low pH? J. Dairy Sci. 8: 1503-1509.

Satter, L. D. and L. L. Slyter. 1972. Effect of ammonia concentration on ruminal microbes in vitro. J. Anim. Sci. 35: 237280.

Stern, M. D., A. Bach, and S. Calsamiglia. 2006. New Concepts in Protein Nutrition of Ruminants. 21 $1^{\text {st }}$ Annual Southwest Nutrition \& Management Conference, February 23-24, 2006.

Sung, H. G., Y. Kobayashi, J. Chang, A. Ha, I. H. Hwang, and J. K. Ha. 2007. Low ruminal $\mathrm{pH}$ reduces dietary fiber digestion via reduced microbial attachment. Asian-Aust. J. Anim. Sci. 2: 200-207.

Tiven, N. C. 2011. Kajian minyak sawit kasar yang diproteksi dengan formaldehid sebagai aditif pakan untuk meningkatkan kualitas daging domba. Disertasi Universitas Gadjah Mada, Yogyakarta.

Wang, Y. and T. A. McAllister. 2002. Rumen microbes, enzymes, and feed digestion- a review. Asian-Aust. J. Anim. Sci. 11: 1659-1676. 

Weatherburn, M. W.
hypochlorite $\quad \begin{array}{rr}1967 . & \text { Phenol- } \\ \text { reaction } & \text { for }\end{array}$ determination of ammonia. Anal. Chem. 39: 971-974.
Li, Y. H., M. Ding, J. Wang, G. J. Xu, F. Zhao. A novel thermoacidophilic endoglucanase, Ba-EGA, from a new cellulose-degrading bacterium, Bacillus sp. AC-1. Appl. Microbiol. Biotechnol. 70: 430-436. 